\title{
Socio-economic and Gender aspects of Arsenicosis - A Case Study in Rural West Bengal (India).
}

\author{
Abhijit Das \\ Assistant Professor, Department of Economics, Kandi Raj College, Kandi, Murshidabad West Bengal, India
}

\begin{abstract}
With an aim to study the impacts of social as well as demographic factors of arsenicosis, a total number of 200 respondents have been interviewed on the basis of a structured questionnaire in arsenic affected rural areas under Murshidabad district of West Bengal. Using Logistic regression model it has been observed that respondents' income, age, gender and education play a significant role in augmenting or lowering this risk. The most significant finding of this study is that the worst affected of the arsenic-related disease is the poor male working groups mainly belong to agricultural activities. There exists significant poverty and gender related differences in access to health care for arsenicosis. Gender discrimination was also reflected through expenditure on medical treatment. The findings of this study may help the policymakers and planners at the national level to determine the target population for prevention and treatment in public health programmes.
\end{abstract}

Key words: Arsenicosis, Socio-demographic factors, Gender aspect, Logistic regression model, Murshidabad district.

\section{Introduction}

Access to the safe water supply is one of the most important determinants of health and socioeconomic development [1]. To overcome the problem of microbiologically unsafe and untreated surface water, more emphasis is given on groundwater use in West Bengal. In seventies the use of surface water got replaced by heavy dependence on groundwater. During eighties, the use of groundwater reached a large proportion. This has been considered as a step that contributed to decreasing the infant mortality rate [2]. In 1983, however, it was discovered that these tubewells which is the major source of drinking and cooking water in West Bengal, are contaminated by naturally occurring arsenic [3]. Estimates are that at present the total population at risk in the state is approximately 28.7 million, 36\% out of the total population of 80.21 million [4]. About 16.26 million population (35.48\% of the total population of the State) covering 17533 number of habitations are located in the potential risk zone of groundwater arsenic related threat and diseases [5]. The problem of arsenic pollution is declared as national problem in 2002. The five districts- Malda, Murshidabad, Nadia, North 24-Parganas and South-24 Parganas situated at Eastern bank of river Bhagarathi are severely affected and at the Western bank three districts (Burdwan, Howrah, Hoogly) are comparatively less affected. Some parts of Kolkata (Capital of West Bengal) are also affected by groundwater arsenic pollution problem [6]. Arsenic contaminated drinking water is highly toxic and hazardous to human health. From research studies in Bangladesh [7, 8, 9], it was observed that there exists a correlation between socio-economic-demographic factors and the arsenic related health hazards (i.e. arsenicosis). Over Past three decades scientific studies $[10,11,12,13]$ have been undertaken in West Bengal to understand the sources and extent of the problem of arsenic contamination in groundwater. Possible impacts on human health have been studied through epidemiological investigation $[14,15,16,17]$. While much is known about the extent and its probable causes [5,18,19], less is known about the health and socioeconomic and demographic implications.

\section{I.1 Objectives of the Study}

The present study tries to assess (a) the socioeconomic and demographic factors affecting arsenicosis among the people of the households in the arsenic affected areas; (b) to establish whether there is any significant poverty or gender related differences in access to health care as well as medical expenditures for arsenicosis. The findings of this study may help the policymakers and planners at the national level to determine the target population for prevention and treatment in public health programmes.

\section{I.2 Sources of Data}

In this study, a total of 200 respondents were interviewed with a pretested scientific questionnaire in 2011. The respondents were randomly interviewed with some selected questions from several affected rural areas of Raninagar-II block and Jalangi block in Murshidabad district, West Bengal (India). To identify arsenic affected areas as well as arsenic concentration level in the tubewell water samples the study completely rely on the data 
Socio-economic and Gender aspects of Arsenicosis - A Case Study in Rural West Bengal (India).

source published by Public Health Engineering Department of West Bengal Government $\left[\operatorname{PHED}(\mathrm{WB})^{1}\right]$ and School of Environmental Studies of Jadavpur University[SOES(JU) $\left.{ }^{2}\right]$. In this study, arsenicosis was assessed by the standard protocol of observing signs of clinical manifestations and discussing the symptoms. The households in the study area were already exposed to a number of awareness programmes on arsenic contamination. There are many who knew about the arsenic related issues owing to their visits to arsenic clinics. Various socio - economic factors (like income, occupation, education) and demographic factors (like gender, age) were considered at the time of data collection.

\section{II.1 Study area}

\section{Materials and Methods}

A detailed survey study report by SOES and PHED on the groundwater arsenic pollution problem is presented in Table 1 and the location of the Murshidabad district is shown in map 1. The demography of the state of West Bengal in India is as follows: the state consists of 18 districts (considering Purba and Paschim Medinipore as one district) with each district being further divided into several blocks or police station (P.S). Each block is again composed of several clusters of villages with each cluster known as Gram Panchayet (GP) and each GP having several villages.

Murshidabad district is one of the arsenic affected districts in West Bengal with highest number of people at risk (CGWB). The total area of the district is $5324 \mathrm{sq} . \mathrm{km}$. and the total population is 5.9 million [4]. In Murshidabad district except Nabagram and Bharatpur-II, 24 blocks (out of 26) are arsenic affected. Arsenic concentration in drinking water ranges between $3-3000 \mu \mathrm{g} / \mathrm{L}$ (SOES, JU Study). The average level of arsenic concentration in groundwater Murshidabad district is $240 \mu \mathrm{g} / \mathrm{L}$. Many people suffering from arsenicosis have died. It has been estimated that out of 2.5 million almost half 1.2 million people in Murshidabad district consume arsenic contaminated water with arsenic concentrations above $10 \mu \mathrm{g} / \mathrm{L}$ and $50 \mu \mathrm{g} / \mathrm{L}$ levels respectively [20].

Table 1: Arsenic Concentration in Nineteen Blocks of Murshidabad Districts

\begin{tabular}{|c|c|c|c|c|c|c|c|c|c|c|}
\hline \multirow{3}{*}{$\begin{array}{l}\text { Sl. } \\
\text { No. }\end{array}$} & \multirow{3}{*}{$\begin{array}{l}\text { Blocks of } \\
\text { Murshidabad } \\
\text { District }\end{array}$} & \multicolumn{9}{|c|}{ Average Arsenic Concentration $(\mu \mathrm{g} / \mathrm{L})$} \\
\hline & & \multicolumn{3}{|c|}{ Whole Frequency Distribution } & \multicolumn{3}{|c|}{$\begin{array}{l}\text { From WHO Level } \\
(10 \mu \mathrm{g} / \mathrm{L})\end{array}$} & \multicolumn{3}{|c|}{$\begin{array}{l}\text { From National Standard } \\
(50 \mu \mathrm{g} / \mathrm{L})\end{array}$} \\
\hline & & JPOA & SOES & Combined & JPOA & SOES & Combined & JPOA & SOES & Combined \\
\hline 1 & Nowda & 67.15 & 48.34 & 58 & 74.86 & 74.53 & 75 & 158.56 & 163.98 & 161 \\
\hline 2 & Hariharpara & 83.48 & 83.25 & 83 & 117.62 & 129.92 & 124 & 203.00 & 218.74 & 211 \\
\hline 3 & Beldanga-I & 89.92 & 85.21 & 88 & 124.23 & 137.80 & 131 & 196.25 & 219.55 & 208 \\
\hline 4 & Berhampur & 58.08 & 29.78 & 44 & 58.08 & 60.88 & 59 & 115.25 & 120.75 & 118 \\
\hline 5 & Beldanga-II & 35.98 & 23.81 & 30 & 71.26 & 60.13 & 66 & 132.33 & 116.65 & 124.5 \\
\hline 6 & Farakka & 33.87 & 32.94 & 33 & 43.92 & 42.23 & 43 & 97.79 & 80.67 & 89 \\
\hline 7 & Suti-I & 30.14 & 81.90 & 56 & 67.53 & 117.11 & 92 & 130.24 & 150.73 & 141 \\
\hline 8 & Suti-II & 60.10 & 83.28 & 72 & 73.49 & 101.26 & 87 & 146.39 & 189.16 & 168 \\
\hline 9 & Samserganj & 39.96 & 46.23 & 43 & 46.88 & 57.87 & 52 & 99.58 & 120.72 & 110 \\
\hline 10 & Raghumathganj-I & 18.55 & 22.45 & 21 & 45.46 & 110.71 & 78 & 118.00 & 155.42 & 137 \\
\hline 11 & Raghumathganj-II & 70.98 & 65.80 & 68 & 80.84 & 86.64 & 84 & 124.90 & 124.11 & 125 \\
\hline 12 & Bhagwangola -I & 55.55 & 61.23 & 58 & 83.36 & 98.35 & 91 & 133.17 & 166.58 & 150 \\
\hline 13 & Bhagwangola -II & 83.90 & 102.52 & 93 & 104.02 & 141.94 & 123 & 173.71 & 216.88 & 195 \\
\hline 14 & M -J Block & 46.79 & 25.56 & 36 & 80.95 & 54.17 & 68 & 131.65 & 102.04 & 117 \\
\hline 15 & Lalgola & 27.53 & 63.83 & 46 & 50.34 & 86.41 & 68 & 110.60 & 149.65 & 130 \\
\hline 16 & Jalangi & 111.11 & 138.03 & 125 & 156.79 & 177.53 & 167 & 229.56 & 258.50 & 244 \\
\hline 17 & Raninagar -I & 78.13 & 58.79 & 69 & 111.47 & 84.32 & 98 & 184.72 & 133.65 & 159 \\
\hline 18 & Raninagar-II & 96.60 & 104.93 & 101 & 176.12 & 156.84 & 166.5 & 280.73 & 247.30 & 264 \\
\hline 19 & Domkal & 79.04 & 80.14 & 80 & 116.43 & 113.64 & 115 & 185.69 & 195.86 & 191 \\
\hline
\end{tabular}

Source- Authors' estimation (Calculated on the basis of PHED report, 2006 and SOES (JU) report, 2006)

\footnotetext{
${ }^{1}$ PHED (WB) is a nodal agency to provide safe water to the rural West Bengal. In collaboration with UNICEF a systematic record on arsenic concentration in tubewell water (Districtwise) in West Bengal was reported under Joint Plan of Action Study (JPOA).

${ }^{2}$ SOES(JU) Research team have dermatologist, geologist, neurologist, economist, social scientists, bio-chemist and environmentalist working on arsenic problem and its health effects in Ganga-Meghna-Brahmaputra(GMB) plain and Bangladesh more than two decades.
} 


\section{Map 1: Location of Murshidabad District and the Study Area}

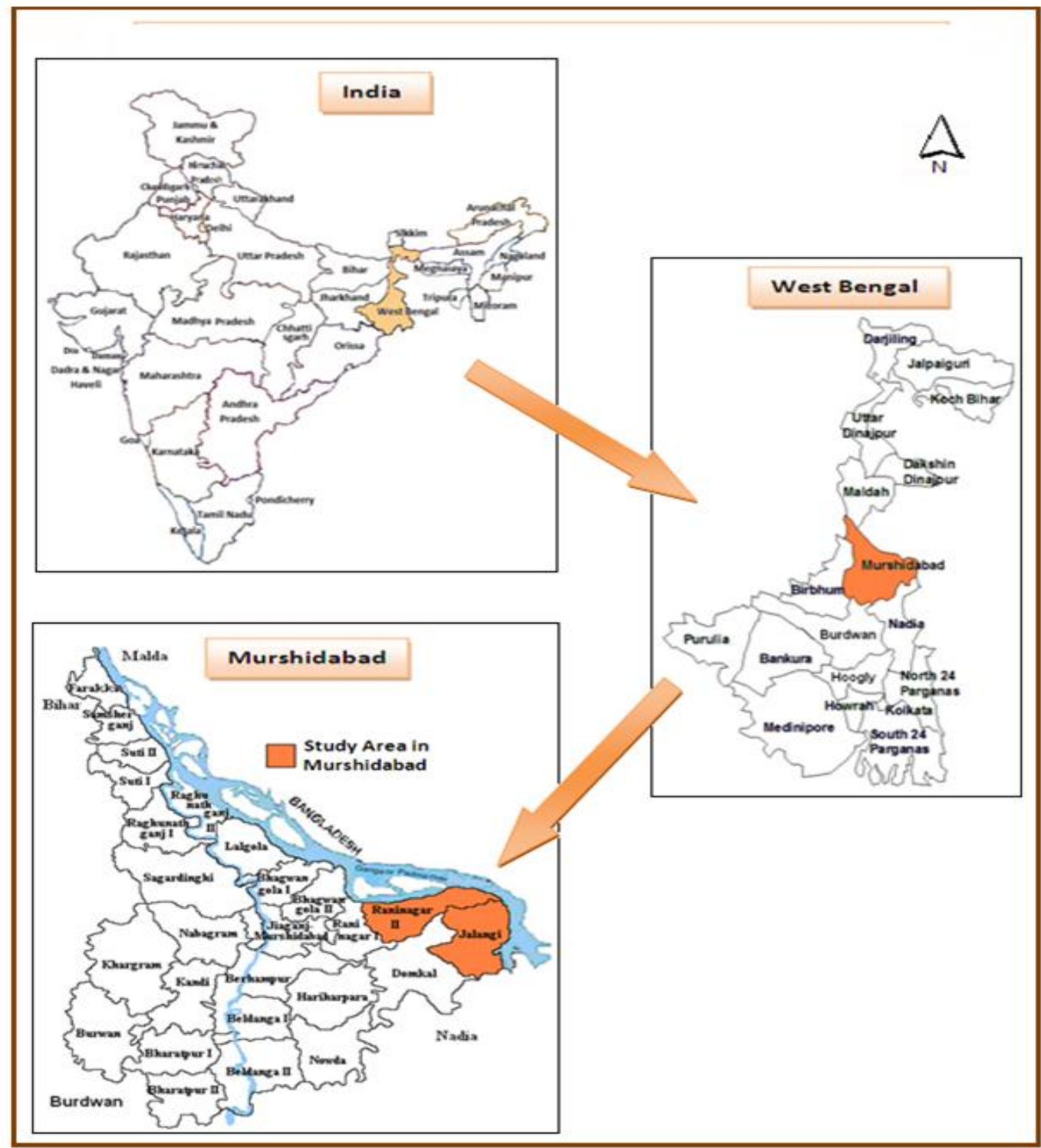

\section{II.2 Data collection}

To collect data several steps were followed. The first step was to identify blocks and villages with habitations that have the highest level of arsenic concentration. We ranked the blocks on the basis of arsenic concentration level. Jalangi and Raninagar-II are the most affected blocks (Table 1). These two blocks are chosen for our study area. At the next stage while selecting the villages in the selected blocks we followed the same procedure as block selection, using village level arsenic concentration information and ranked them in descending order of arsenic concentration (Table A and Table B in Appendix ). With our study objectives in mind total 200 respondents were interviewed (taking 100 from each block) in the study area using pretested questionnaire.

Household selection was done through random sampling. We visited all chosen habitations and identified the shallow tube wells for which concentration levels are reported. Then listed the households in the command area of each water source and randomly selected the number of households that they would interview. The number of households surveyed in each command area varied depending on the size of the command area. A key aspect of the survey was to elicit arsenic disease related information through both direct questioning of the households and the knowledge that we have gathered from the preliminary discussions with expert dermatologists in Kolkata. In the study area we know, households were exposed to arsenic-awareness campaigns. Many also knew about their diseases because of visits to arsenic clinic. We identified some categories of arsenic related diseases: melanosis, keratosis, vascular disease, ulcer, lung problem, cancer etc. 


\section{Results and Discussions}

\section{III.1 Socio-economic and demographic Profile of the Respondent}

The socioeconomic and demographic features of surveyed respondents are presented in Table 2. Respondents comprised 174 males and 26 females. Average age of the respondents was 44.58 . About $11 \%$ of the population having age $<30$ years, $24.5 \%$ were within the age group (30-40), 33\% were within the age group (40-50), $21 \%$ fell in the age group (50-60), 10.5\% having age $\geq 60$ years. The average size of the family member was 5. Among the respondents $47.5 \%$ had no formal education and $52.5 \%$ had education (13\% completed primary education, $17.5 \%$ completed upper primary education, $12 \%$ completed secondary education, $10 \%$ had higher secondary and college education). The mean year of schooling among the literates was just 7.48. As the survey covered only rural households, a significant number of respondents $(62.5 \%)$ were engaged in agricultural and related activities, $17.5 \%$ of the respondents in the sample area were engaged in the nonagricultural activities (includes service, business and self-employed) and 20\% of the respondents were housewives, students and unemployed considered as other categories. The respondents have been classified by income categories also. The lowest income category with monthly income levels equal to or less than Rs.2000 represents the low income category followed by middle (income range Rs.2000 to Rs.6000) and higher income (income above Rs.6000) categories. A significant number of respondents (56.5\%) fall under low-income category, $41 \%$ fall under middle income category and $2.5 \%$ fall under high income category.

Table 2: Socioeconomic and Demographic Profile of the Respondents

\begin{tabular}{|c|c|c|c|c|c|c|}
\hline \multirow{2}{*}{$\begin{array}{l}\text { Characteristics of the } \\
\text { Respondent }\end{array}$} & \multicolumn{2}{|c|}{ Total } & \multicolumn{2}{|c|}{ Raninagar-II } & \multicolumn{2}{|c|}{ Jalangi } \\
\hline & $\mathrm{n}=\mathbf{2 0 0}$ & $\%$ & $\mathrm{n}_{1}=\mathbf{1 0 0}$ & $\%$ & $\mathrm{n}_{2}=100$ & $\%$ \\
\hline \multicolumn{7}{|l|}{ Age(years) } \\
\hline$<30$ & 22 & 11 & 14 & 14 & 8 & 8 \\
\hline $30-40$ & 49 & 24.5 & 29 & 29 & 20 & 20 \\
\hline $40-50$ & 66 & 33 & 34 & 34 & 32 & 32 \\
\hline $50-60$ & 42 & 21 & 15 & 15 & 27 & 27 \\
\hline$\geq 60$ & 21 & 10.5 & 8 & 8 & 13 & 13 \\
\hline Mean & 44.58 & & 41.08 & & 46.08 & \\
\hline \multicolumn{7}{|l|}{ Gender } \\
\hline Female & 26 & 13 & 12 & 12 & 14 & 14 \\
\hline Male & 174 & 87 & 88 & 88 & 86 & 86 \\
\hline Average Family Member & 5 & & 4.9 & & 5.1 & \\
\hline \multicolumn{7}{|l|}{$\begin{array}{l}\text { Educational status of the } \\
\text { Respondent }\end{array}$} \\
\hline No education & 95 & 47.5 & 48 & 48 & 47 & 47 \\
\hline Primary (1-4) & 26 & 13 & 11 & 11 & 15 & 15 \\
\hline Upper primary $(5-8)$ & 35 & 17.5 & 18 & 18 & 17 & 17 \\
\hline Secondary $(9-10)$ & 24 & 12 & 10 & 10 & 14 & 14 \\
\hline Higher secondary(11-12) & 10 & 5 & 5 & 5 & 5 & 5 \\
\hline $\begin{array}{l}\text { College and Higher education } \\
(>12)\end{array}$ & 10 & 5 & 8 & 8 & 2 & 2 \\
\hline Mean & 7.48 & & 7.98 & & 6.95 & \\
\hline \multicolumn{7}{|l|}{$\begin{array}{l}\text { Major occupation of the } \\
\text { respondent }\end{array}$} \\
\hline Agricultural activities & 125 & 62.5 & 66 & 66 & 59 & 59 \\
\hline $\begin{array}{l}\text { Non-agricultural activities } \\
\text { (includes Business, service, self- } \\
\text { employment) }\end{array}$ & 35 & 17.5 & 16 & 16 & 19 & 19 \\
\hline $\begin{array}{l}\text { Others (Housewife, Students, } \\
\text { unemployed) }\end{array}$ & 40 & 20 & 18 & 18 & 22 & 22 \\
\hline \multicolumn{7}{|l|}{$\begin{array}{l}\text { Economic status of the } \\
\text { Respondent (income group) }\end{array}$} \\
\hline Low income $(0-2000)$ & 113 & 56.5 & 62 & 62 & 51 & 51 \\
\hline Medium income(2000-6000) & 82 & 41 & 35 & 35 & 47 & 47 \\
\hline High income( $6000 \&$ above $)$ & 5 & 2.5 & 3 & 3 & 2 & 2 \\
\hline
\end{tabular}




\section{III.2 Study of the Risk Factors}

Almost $57 \%$ of the population that has been studied had arsenic lesions on their skin. The risk factors are greatly determined by age and gender differences, as the study has shown. Almost $70 \%$ of the productive age group (within 30- 50 years of age) is affected by Arsenicosis. Comparatively women are less affected by the same. The reason may be they are primarily engaged in domestic work and fetch water for household purposes either from their own tube well at home or the hand pumps in the vicinity, in case they do not have any private tube wells. From a great number of households that have been surveyed, women fetched water for domestic use from the nearby hand pumps which were deemed safe by the authority. On the other hand most men in the study village are landless labourers who work on the basis of daily wage and have to visit all over the villages for their work. They have to drink water from multiple sources. They consume water mostly from irrigation pumps and this is one of the most important sources of arsenic poisoning for them. For the very same reason, the number of persons who are affected by Arsenicosis is far greater in the case of their engagement in agricultural activities $(62.4 \%)$ than that in non agricultural activities $(54.29 \%)$ or that in others $(40 \%)$. More educated people (who have studied at least till Higher Secondary level) are seen to be less affected (less than 50\% of them are affected) by the disease than the less educated ones (who have not studied beyond the Secondary level). It has been seen that in the lower and middle income groups, the number of people suffering from arsenic related health hazards is far greater than in the higher income group. That the higher income groups are relatively safer may be due to their food intake which is definitely more nutritious than that of the two lower groups.

Table 3: Socio-economic and demographic variables Vs arsenicosis

\begin{tabular}{|c|c|c|c|}
\hline Characteristics of the Respondent & $\begin{array}{c}\text { No. of } \\
\text { Respondents }\end{array}$ & $\begin{array}{l}\text { Affected by } \\
\text { Arsenicosis }\end{array}$ & $\%$ \\
\hline \multicolumn{4}{|l|}{ Age(years) } \\
\hline$<30$ & 22 & 14 & 63.63 \\
\hline $30-40$ & 49 & 36 & 73.47 \\
\hline $40-50$ & 66 & 47 & 71.21 \\
\hline $50-60$ & 42 & 14 & 33.33 \\
\hline$\geq 60$ & 21 & 2 & 9.52 \\
\hline \multicolumn{4}{|l|}{ Gender } \\
\hline Female & 26 & 12 & 46.15 \\
\hline Male & 174 & 101 & 58.01 \\
\hline \multicolumn{4}{|l|}{ Educational status of the Respondent } \\
\hline No education & 95 & 56 & 58.95 \\
\hline Primary $(1-4)$ & 26 & 17 & 65.38 \\
\hline upper primary $(5-8)$ & 35 & 20 & 57.14 \\
\hline Secondary $(9-10)$ & 24 & 12 & 50 \\
\hline Higher secondary(11-12) & 10 & 4 & 40 \\
\hline Collage and Higher education $(>12)$ & 10 & 4 & 40 \\
\hline \multicolumn{4}{|l|}{ Major occupation of the respondent } \\
\hline Agricultural activities & 125 & 78 & 62.4 \\
\hline $\begin{array}{l}\text { Non-agricultural activities (includes Business, } \\
\text { service, self-employment) }\end{array}$ & 35 & 19 & 54.29 \\
\hline Others (Housewife, Students, unemployed) & 40 & 16 & 40 \\
\hline \multicolumn{4}{|l|}{$\begin{array}{l}\text { Economic status of the Respondent (income } \\
\text { group) }\end{array}$} \\
\hline Low income $(0-2000)$ & 113 & 70 & 61.95 \\
\hline Medium income(2000-6000) & 82 & 42 & 51.22 \\
\hline High income $(6000 \&$ above $)$ & 5 & 1 & 20 \\
\hline
\end{tabular}

\section{III.3 Gender Disparity in taking Medical Treatment}

$73 \%$ of the arsenic patients received medical treatment. Male and female respondents were compared in terms whether the affected member of the households received treatment for arsenicosis. A clear gender disparity was observed in treatment-seeking behaviour for arsenicosis (Table 4). Males sought medical treat more than women ( $76 \%$ for males and $42 \%$ for females). The reasons for such gender disparity of seeking medical help from registered practitioners ranges from social to economic. Transport cost becomes an economic burden over and above the expenditure for treatment. Moreover in a strong patriarchal society women are not allowed to venture out of home alone too often and this has restricted them within the confines of the local 
Socio-economic and Gender aspects of Arsenicosis - A Case Study in Rural West Bengal (India).

doctors in their villages. For example, only men visited Kolkata for treatment (where proper medical facilities are available and it is approximately $250 \mathrm{~km}$ away from the surveyed villages).

Table 4: Gender Disparity in Taking Medical Treatment

\begin{tabular}{|l|c|c|c|}
\hline \multirow{2}{*}{\multicolumn{1}{|c|}{ Income Group }} & \multicolumn{3}{|c|}{ Number of Patients taking medical treatment } \\
\cline { 2 - 4 } & Male & Female & Total \\
\hline Low Income (Group-I) & 44 & 3 & 47 \\
\hline Middle Income (Group-II) & 32 & 2 & 34 \\
\hline High Income (Group-III) & 1 & 0 & 1 \\
\hline Total & 77 (out of 101) & 5 (out of 12) & 82(out of 113) \\
\hline
\end{tabular}

Figure 1: Arsenic Patients Taking Medical Treatment

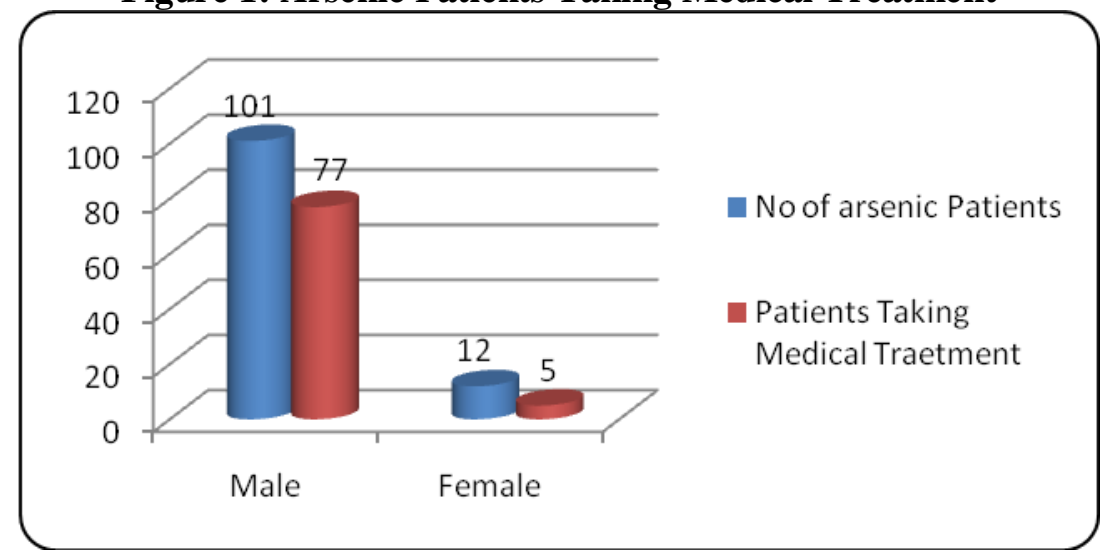

Figure 2: Gender Disparity in Treatment Seeking Behaviour

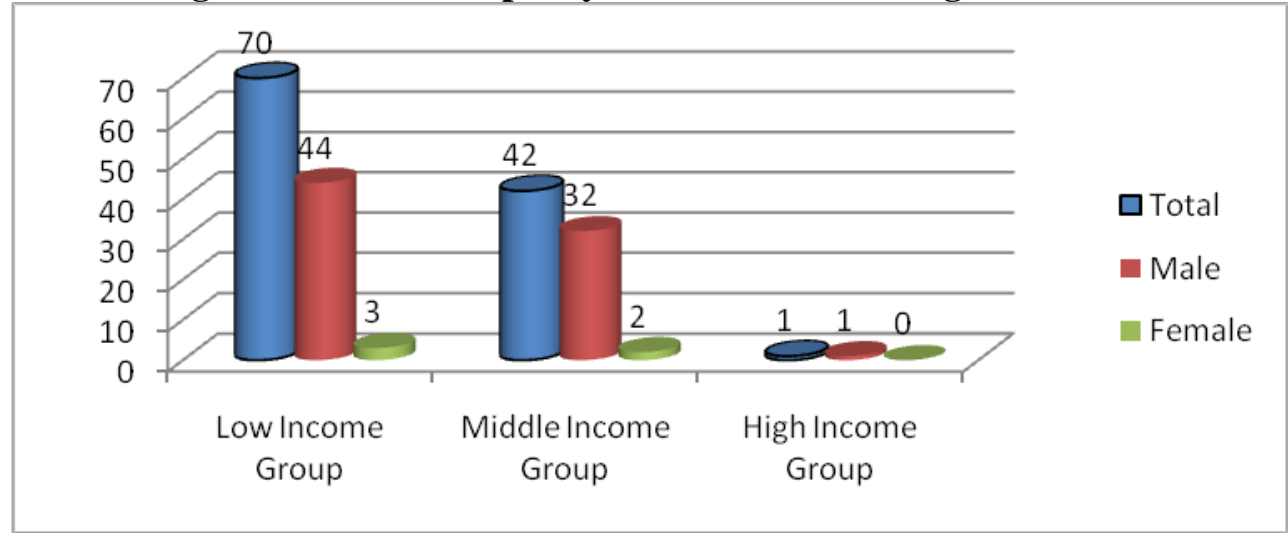

\section{III.3.1 Source for Financing Medical Expenditures}

Gender discrimination was also reflected through expenditure on medical treatment. For treatment of males, borrowing money or selling household property were the sources of money though debt is less for treatment. For example, selling assets for medical care of males is $67 \%$, for females is $33 \%$ and expenditure procured by reducing family expenditures is $93 \%$ for males and $7 \%$ for females and more than one ways (like taking loan, selling off properties, reducing family expenditures) is $89 \%$ for males, for females is $11 \%$. Two reasons why more attention was paid towards males' medical treatment are traditional gender bias towards males and more severe manifestation of symptoms of arsenic poisoning among males.

Table 5: Management of Money for Treatment Expenditures

\begin{tabular}{|c|c|c|c|}
\hline \multirow{2}{*}{ Ways } & \multicolumn{2}{|c|}{ Number of Households/Respondents reported money management } \\
\cline { 2 - 4 } & For Male Patients & $\begin{array}{c}\text { For Female } \\
\text { patients }\end{array}$ & Total \\
\hline Only by Reducing family expenditures & $39(92.86)$ & $3(7.14)$ & $42(54.53)$ \\
\hline Only by Selling assets & $2(66.67)$ & $1(33.33)$ & $3(4.11)$ \\
\hline Only by Taking loan & 0 & 0 & 0 \\
\hline More than one ways & $25(89.29)$ & $3(10.71)$ & $28(58.36)$ \\
\hline
\end{tabular}

Note: Figures in the parentheses are percentages 
Figure 2: Source of Finance to Treat Arsenic Patients in the Family

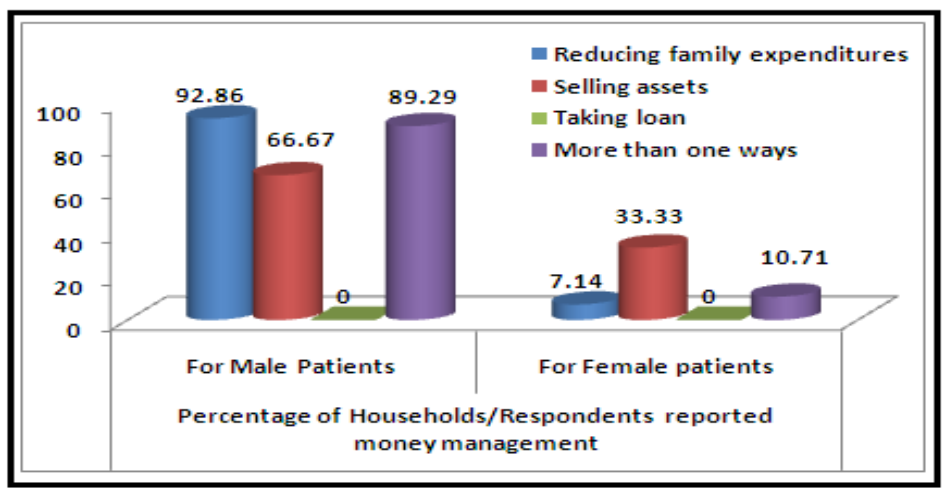

\section{An Econometric Analysis}

We have carried regression analysis to discern causal relation and relative strength of determining variables to help in deriving policy implications. Here we treat 'occurrence of arsenicosis' as a dependent variable. Because of the dichotomous nature of the dependent variable, logistic regression analysis was carried out using the statistical software STATA (Version 10). Let $\mathrm{Z}$ be the occurrence of arsenicosis that is, a dichotomous dependent variable, which takes values 1 and $0 . \mathrm{Z}$ is classified in the following way:

$$
\mathrm{Z}_{\mathrm{i}}=\left\{\begin{array}{l}
1, \text { arsenicosis is occured } \\
0, \text { otherwise }
\end{array}\right.
$$

The model helps in estimating the probability of occurrence of an event and is given by $\mathrm{P}_{\mathrm{i}}=$ Probability (event) $=1 /\left(1+\mathrm{e}^{-\mathrm{z}} \mathrm{i}\right)$

Where $\mathrm{Z}_{\mathrm{i}}$ is the linear combination of variables $\mathrm{X}_{1}, \mathrm{X}_{2}, \mathrm{X}_{3} \ldots \ldots \ldots, \mathrm{X}_{\mathrm{q}}$

$Z_{i}=\alpha_{0}+\alpha_{1} X_{1}+\alpha_{2} X_{2}+\alpha_{3} X_{3}+\ldots \ldots \ldots+\alpha_{q} X_{q}$

If $\mathrm{P}_{\mathrm{i}}$ is the probability of occurring the event, then $\left(1-\mathrm{P}_{\mathrm{i}}\right)$ is the probability of not occurring the event.

Therefore, we can write

$\mathrm{P}_{\mathrm{i}} /\left(1-\mathrm{P}_{\mathrm{i}}\right)=1+\mathrm{e}_{\mathrm{i}}^{\mathrm{z}} / 1+\mathrm{e}_{\mathrm{i}}^{-\mathrm{z}}=\mathrm{e}_{\mathrm{i}}^{\mathrm{z}}$

Now, $\mathrm{P}_{\mathrm{i}} /\left(1-\mathrm{P}_{\mathrm{i}}\right)$ is simply the odd-ratio in favour the event.

The above probability expression can be transformed to determine the log odds in favour of the event as $\mathrm{L}=\log [\operatorname{Prob}($ event $) /\{1-$ Prob (event) $\}]=\alpha_{0}+\alpha_{1} X_{1}+\alpha_{2} X_{2}+\alpha_{3} X_{3}+\ldots+\alpha_{q} X_{q}$

the $\log$ of odd ratio is not only linear in $\mathrm{X}$, but also linear in parameters $\alpha \mathrm{i}$, the slope measures the change in $\mathrm{L}$ for a unit change in $\mathrm{X}$, that is, it tells how the log-odds in favour of the event.

IV.1. Model Specification

It is postulated that the probability of an individual suffering from the arsenicosis depends on the following attributes

a. Income of the individual(INC)

b. Age of the individual (AGE)

c. Gender of the individual (GEN)

d. Education of the individual (EDU)

Thus equation (1) can be rewritten as

$Z=\beta_{1}+\beta_{2}(\mathrm{INC})+\beta_{3}(\mathrm{AGE})+\beta_{4}(\mathrm{GEN})+\beta_{5}(\mathrm{EDU})$

Education of the respondent is considered as dummy variable [literate $=1$, illiterate $=0$ ]. Estimated values of the parameters $\beta_{1}$ to $\beta_{5}$ can be used to describe the probability of a person suffering from the arsenicosis.

IV.2. Logit analysis for the prevalence of arsenicosis

The role of the selected risk factors in explaining the prevalence of arsenicosis was examined by logit regression analysis. Empirical analysis through the estimation of logit model helps us to get the nature and magnitude of the coefficients of the equation (2). Respondent's income, age, gender and education were considered as predictors.

Table 6 gives the estimated coefficient values of the variables and corresponding p-values. The variable income (INC) has expected sign and statistical significance. Thus the probability of $100 \%$ prevalence of arsenicosis among the low income people is established. Respondent's ages (AGE), gender (GEN) and education (EDU) all have a high significant impact on arsenicosis. 
Socio-economic and Gender aspects of Arsenicosis - A Case Study in Rural West Bengal (India).

\begin{tabular}{ccc}
\multicolumn{3}{c}{ Table 6: Parameter Estimates } \\
\hline Variable & Coefficient & p-value \\
\hline INC & -0.000306 & 0.031 \\
AGE & -0.1018482 & 0.000 \\
GEN & 2.672388 & 0.000 \\
EDU & -0.0942487 & 0.018 \\
\hline
\end{tabular}

As the model assumes a non-linear functional relationships between the dependent and independent variables, the marginal effects of each of the independent variables are also reported (Table 7). These marginal effects can be interpreted as the increment in the probability of taking medical treatment due to an increase in any one of the independent variable by $1 \%$. The statistical results of the Table 7 explain that all the variables have significant marginal contribution on the dependent variable.

Table 7: Marginal Effects

\begin{tabular}{ccc}
\hline Variable & Marginal effect(dy/dx $)$ & p-value \\
\hline INC & -0.0000744 & 0.032 \\
AGE & -0.024747 & 0.000 \\
GEN & 0.5444093 & 0.000 \\
EDU & -0.0229005 & 0.017 \\
\hline
\end{tabular}

\section{Conclusion and Recommendation}

Hence from the above discussion it follows that the occurrence of arsenicosis and the level of household's income is negative. The number of arsenic affected male patients is much higher than the female ones. People engaged in agricultural activities are definitely more exposed to this threat than the people involved in non agricultural activities. The poor population pays the highest cost due to groundwater arsenic pollution as they are already made vulnerable by their poor socio- economic standards of living. This also poses a great health threat to the most productive section of the society. As the study shows the men within the age group of 30-50 years are the worst affected by this problem, what follows from here that the dependency ratio in these villages will increase and productivity and life expectancy will be significantly lowered in the near future. The meeting of the Millennium Development Goals seems more difficult. What is recommended is that the health care system can be selective in distribution of health service by introducing appropriate institutional mechanisms so that it can cater more to the low income and the most vulnerable section of the society. Greater emphasis should be placed on the provision of arsenic free safe water to be made easily available to the people of the affected areas which would surely yield direct health benefits to the patients of Arsenicosis as well. More knowledge intensive and more frequent awareness programmes have to be organized in the affected areas. Along with the regular awareness programmes where all the villagers are supposed to assemble at a designated time, dissemination programmes through various research surveys which are individualized by research teams as well as peer to peer communication should be made more frequent. Involvement of the patients in information dissemination is necessary as they can be the live example of the health hazards of groundwater arsenic pollution as well as the dire need for arsenic free safe drinking water. To list the most sparsely served areas is important to make the awareness programmes widespread. Schools and colleges should be also included as the young students educated there can in turn educate their families and there lies a promise of a better future. Trainers' training programmes can be introduced through which school and college teachers as well as school children can become the great champions of this cause and help the information dissemination produce more effect.

\section{Acknowledgement}

Author acknowledges with thanks the financial support from the University Grants Commission (Eastern Regional Office, Kolkata) under the Minor Research Project grant scheme (No.PHW-119/11-12) part of which has helped in conducting the pilot survey. I am thankful to Professor Joyashree Roy of Department of Economics and Professor Dipankar Chakraborti of SOES (JU), Jadavpur University for their valuable suggestions.

\section{References}

[1]. B. Cvjetanovic, Health effects and impact of water supply and sanitation, World Health Statistics Quarterly. 39(1), 1986, $105-117$.

[2]. Water Aid, Drinking water quality in rural India: issues and approaches, Drinking water quality background paper. Available at http://www.wateraid.org/documents/ plugin_documents/drinking_water.pdf. Viewed on 10 January, 2011. 
[3]. K.C Saha, Malignancy in Arsenicosis, Proceedings of the International Workshop on Control of Arsenic Contamination in Groundwater, Public Health Engineering Department, Government of West Bengal during 5-6 January at Kolkata, India, 2000, 195199.

[4]. Census of India (2001): Registrar General \& Census Commissioner, India. (http:// www.censusindia.gov.in/Census_Data_2001/India_at_glance/rural.aspx). Viewed on $17^{\text {th }}$ February, 2011.

[5]. Report of National Institute of Hydrology (NIH), Roorkee Central Ground Water Board (CGWB), New Delhi Under the aegis of: Ministry of Water Resources Government of India New Delhi, 2010.

[6]. B. Das, Investigation for Safe Water Options in Groundwater Arsenic Contaminated Rural and Urban Settlements in Lower Ganga Plain, doctoral dissertation, Jadavpur University, 2010.

[7]. A. Hadi and R Parveen, Arsenicosis in Bangladesh: Prevalence and socio-economic correlates", Public Health, 118, $2004,559-564$.

[8]. M. Hossain and R Islam, Arsenicosis in rural areas of Bangladesh: Socio-demographic Correlation", Journal of Geography and Regional Planning, 2(9), 2009, 231-234.

[9]. S A I Mahmood and A K Halde, The Socio-economic impact of Arsenic poisoning in Bangladesh", Journal of Toxicology and Environmental Health Sciences, 3(3), 2011, 65-73.

[10]. D. Das, G Samanta, B K Mandal, T R Chowdhury, C R Chanda, P P Chowdhury, G K Basu, D Chakraborti, Arsenic in Groundwater in six districts of West Bengal, India: biggest calamity in the world", Environ Development health, 18,1996, 5-15.

[11]. D K Chadha and S P Sinha Ray, High Incidence of arsenic in Groundwater in West Bengal", Central Ground Water Board, Ministry of Water Resources, Faridabad, India, 1999.

[12]. D Chakraborti, G K Basu, B K Biswas, U K Chowdhury, M M Rahman, K Paul, T R Chowdhury, C R Chanda, D Lodh, Characterization of arsenic-bearing sediments in the Gangetic delta of West Bengal, India", In: Arsenic Exposure and Health Effects, Chappell, W.R.; Abernathy, C.O.; Calderon, R.L. (ed.), Elsevier, Amsterdam-Lausanne-New York- Oxford-Tokyo, 2001, 27-52.

[13]. D Chakraborti, B Das, M M Rahman, U Kumar Chowdhury, B Biswas, A. B. Goswami, B Nayak, A Pal, M K Sengupta, Sad Ahamed, A Hossain, GBasu, T Roychowdhury and D Das, Status of groundwater arsenic contamination in the state of West Bengal, India: A 20-year study report". Mol. Nutr. Food Res. 53, 2009, 542-551.

[14]. K C Saha, D Chakraborti, Seventeen Years Experience of Arsenicosis in West Bengal, India" in Chappell et.al (ed.), Arsenic Exposure and Health Effects, 2001, 387-396. Publisher: Elsevier, Amsterdam-Lausanne-New York-Oxford-Tokyo.

[15]. K C Saha, Saha's grading of arsenicosis progression and treatment, In: Chappell, W.R., Abernathy, C.O., Calderon, R.L. \& Thomas, D.J. (ed.) Arsenic Exposure and Health Effects V. Amsterdam: Elsevier, 2003, 391-414.

[16]. D N Guha Mazumder, R Haque, N Ghosh, B K De, A Santra, D Chakraborti, A Smith, Arsenic Levels in Drinking Water and the Prevalence of Skin Lesions in West Bengal, India", International Journal of Epidemiology, 27, 1998,871-77.

[17]. D N Guha Mazumder, R Haque, N Ghosh, B K De, A Santra, D Chakraborti, A Smith, Arsenic in Drinking Water and the Prevalence of Respiratory effects in West Bengal, India"- International Journal of Epidemiology, 29(6), 2000, 1047-1042.

[18]. M K Sengupta, Situation of Groundwater Arsenic Contamination Problem and Human Sufferings in West Bengal, doctoral dissertation, Jadavpur University, 2006.

[19]. Reports of Public Health Engineering Directorate (PHED), Government of West Bengal, Arsenic Contamination in Groundwater of West Bengal- Strategy and action taken, 2008.

[20]. M M Rahman, M K Sengupta, S C Mukherjee; S Pati ; A Sad; D Lodh; B Das; A Hossain; B Nayak; K C Saha ; S K Palit; I Karies ; A K Barua ; A A Khondakar ; A Mukherjee; D Chakraborti D , Murshidabad - one of the nine groundwater arsenic affected districts of West Bengal, India”. Part I and Part II. Journal of Toxicology - Clinical Toxicology, 43, 2005, 823-834.

Appendix A

Table A: Arsenic Concentration in Jalangi Block

\begin{tabular}{|c|c|c|c|c|c|c|c|c|c|}
\hline \multirow[t]{2}{*}{ Block } & \multicolumn{9}{|c|}{ Average Concentration $(\mu \mathrm{g} / \mathrm{L})$} \\
\hline & \multicolumn{3}{|c|}{ Whole Frequency Distribution } & \multicolumn{3}{|c|}{$\begin{array}{l}\text { From WHO Level } \\
\qquad(10 \mu \mathrm{g} / \mathrm{L})\end{array}$} & \multicolumn{3}{|c|}{$\begin{array}{l}\text { From National Standard } \\
(50 \mu \mathrm{g} / \mathrm{L})\end{array}$} \\
\hline JALANGI & JPOA & SOES & COMBINED & JPOA & SOES & COMBINED & JPOA & SOES & COMBINED \\
\hline Sagarpara & 172 & 181.29 & 177 & 212.09 & 211.22 & 212 & 278.90 & 302.42 & 291 \\
\hline Kharamarai & 163 & 175 & 169 & 212.69 & 201.01 & 207 & 286.17 & 279.21 & 283 \\
\hline Sadikhardiar & 191 & 122.41 & 157 & 269.10 & 156.60 & 213 & 403.10 & 242.69 & 323 \\
\hline Faridpur & 68.32 & 80.24 & 74 & 116.92 & 130.47 & 124 & 186.29 & 256.86 & 222 \\
\hline Ghoshpara & 113.45 & 193.79 & 154 & 145.52 & 214.69 & 180 & 204.49 & 260.08 & 232 \\
\hline Debipur & 96.18 & 147.77 & 122 & 124.55 & 163.38 & 144 & 204.06 & 223.69 & 214 \\
\hline Jalangi & 144.52 & 70.83 & 108 & 198.70 & 101.43 & 150 & 218 & 164.94 & 191 \\
\hline Kantabari & 93.16 & 64.76 & 79 & 135.84 & 97.19 & 117 & 197.66 & 188.65 & 193 \\
\hline Choapara & 65.65 & 47.16 & 56 & 95.04 & 75.84 & 85 & 135.80 & 121.69 & 129 \\
\hline Sahebnagar & 68.11 & 26.75 & 47 & 108.84 & 59 & 84 & 211.71 & 106.13 & 159 \\
\hline Block as a whole & 111.11 & 138.03 & 125 & 156.79 & 177.53 & 167 & 229.56 & 258.50 & 244 \\
\hline
\end{tabular}

Appendix B

Table B: Arsenic Concentration in Raninagar-II Block

\begin{tabular}{|c|c|c|c|c|c|c|c|c|c|}
\hline \multirow[t]{2}{*}{ Block } & \multicolumn{9}{|c|}{ Average Concentration $(\mu \mathrm{g} / \mathrm{L})$} \\
\hline & \multicolumn{3}{|c|}{ Whole Frequency Distribution } & \multicolumn{3}{|c|}{$\begin{array}{l}\text { From WHO Level } \\
(10 \mu \mathrm{g} / \mathrm{L})\end{array}$} & \multicolumn{3}{|c|}{$\begin{array}{l}\text { From National Standard } \\
\qquad(50 \mu \mathrm{g} / \mathrm{L})\end{array}$} \\
\hline RANINAGAR-II & JPOA & SOES & COMBINED & JPOA & SOES & COMBINED & JPOA & SOES & COMBINED \\
\hline Malibari- II & 209 & 286 & 248 & 274.11 & 297.76 & 286 & 312.91 & 324.54 & 319 \\
\hline Malibari-I & 122 & 146 & 134 & 201.89 & 175.10 & 188 & 303.75 & 267.13 & 285 \\
\hline Katlamari-I & 130 & 64 & 97 & 191.57 & 125.78 & 159 & 290.61 & 202.75 & 247 \\
\hline Raninagar-II & 60 & 112 & 86 & 140.41 & 149.31 & 145 & 241.26 & 236.10 & 239 \\
\hline Rajapur & 41 & 127 & 84 & 94.63 & 131.79 & 113 & 179.01 & 203.43 & 191 \\
\hline Katlamari-II & 45 & 32 & 39 & 84.75 & 46.87 & 66 & 134.36 & 170.58 & 152 \\
\hline Raninagar-I & 32 & 26 & 29 & 66.27 & 50.25 & 58 & 146.75 & 128.36 & 138 \\
\hline Kalinagar-II & 19 & 21 & 20 & 53.20 & 39.27 & 46 & 132.64 & 121.36 & 127 \\
\hline
\end{tabular}


Socio-economic and Gender aspects of Arsenicosis - A Case Study in Rural West Bengal (India).

\begin{tabular}{|l|c|c|c|c|c|c|c|c|c|}
\hline Kalinagar-I & 16 & 18 & 17 & 52.17 & 46.59 & 49 & 225.50 & 110.57 & 168 \\
\hline Block as a whole & 96.60 & 104.93 & 101 & 176.12 & 156.84 & 166.5 & 280.73 & 247.30 & 264 \\
\hline
\end{tabular}

